\title{
"Un bizarro poema de granito al infinito"1 \\ Modernismo and Nation-building in Philippine Poetry in Spanish
}

\section{Beatriz Álvarez-Tardío \\ Universidad Rey Juan Carlos, Madrid}

\section{Abstract}

This study presents Philippine poetry written in Spanish from 1898 until 1914 in its proper literary and political contexts: Modernismo aesthetics from Spanish-American Literature and language politics and the Independence from the American colonization in the Philippines. It focuses on three Philippine poets--Claro Recto, Cecilio Apóstol and Fernando Guerrero--and on some of their most representative poems. It also provides translations into English for some of the poems not translated previously.

The modernista use of language and the modernista preoccupation for nation and progress were bound together in their poetry. This essay identifies their most significant notions such as: defending the country's heritage against the neocolonialism under the United States; setting the tasks of the intellectuals in confronting their milieu; expressing the distinctive elements of the nation constituents of the project for the nation-building; and the transformation towards a modern culture based upon the roots of that nation in progress. Their use of the Spanish language is still nowadays understood as an epitome of colonial chains and subjugation, underestimating their contributions to the Philippine resistance, their battle for intellectual freedom, and their unrecog- 
nized defense of Tagalog language through the medium of Spanish language. This essay aims at highlighting the Philippine embodiment of Modernismo, while seeking for a deep understanding of the work of these poets within the history of Philippine literature and culture.

\section{Keywords}

Philippine Literature, Fernando M. Guerrero, Claro M. Recto, Cecilio Apostol, Modernismo, Language politics in the Philippines 
During and after the Revolution, from 1896 to 1898 , literary creation in the Philippines experienced a productiveness that extended to a variety of genres and languages. Texts were widely published and spread, mainly thanks to the increasing number of newspapers, journals, and magazines. Many factors contributed to the increasing display of cultural and literary activity and many were also the reasons moving the intellectuals and artists to write. The necessity of self-definition stood as a way of resisting colonization, initially from Spanish powers, but, a few years after, from American occupation, too. The Revolution for Independence brought a short-lived Republic of the Philippines, declared in June of the same year when the US Army defeated the remains of Spanish colonial government in the Philippines that was 1898. The Philippine fight didn't cease so that soon it was declared the PhilippineAmerican War. Although declared over by 1902, it lasted a few years with on-going different levels of violence in the different regions of the country for a decade or so (Agoncillo 247). A Sedition Law (1901) was approved by the American government seeking to forbid expressions for independence and keep social movements under control (Lumbera 87; Cullinane 115).

In such a milieu, Cecilio Apostol (1878-1938), Fernando Maria Guerrero (1870-1932), and Claro Mayo Recto (1890-1960) bound their poetry to the battle for intellectual emancipation by shaping their metaphors in the trend of Modernismo. The reception of the Spanish-American Modernismo in the Philippines through the widely-read works of authors like Rubén Darío or Santos Chocano was concomitant to the birthing of the movement in the Philippines (Álvarez 135-138).

The overlap between terms may require clarification. Modernismo refers to a poetic style, a movement and a period in the literatures in SpanishAmerica, and in Philippine poetry written in Spanish described here in this article. It expanded from around 1870 until the second decade of the $20^{\text {th }}$ century (Jrade 1996; Quiroga 1996; Álvarez 2013). The historical AvantGarde [Vanguardia] in Spanish American poetry "with a period of radical experimentation from 1922 to 1940" (Quiroga 303) is known in the English language and in American-English literary studies as Modernism. There is a further overlaying of terms in the Philippines: Filipino language uses the 


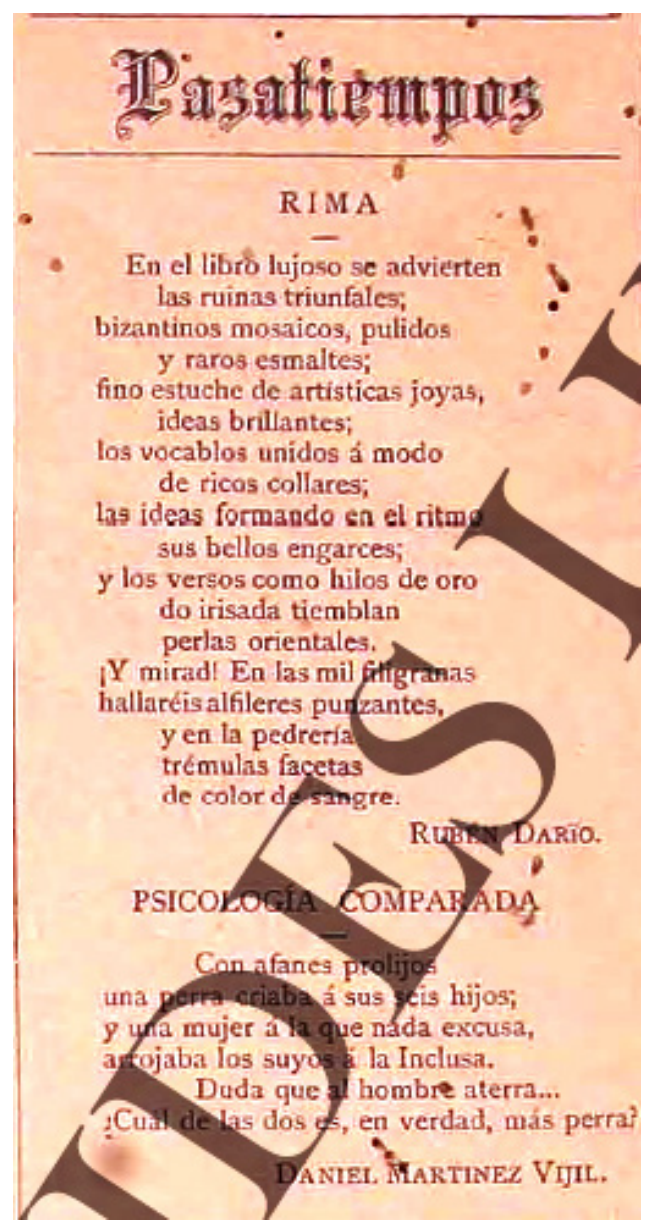

Fig. 1. Poem by Rubén Darío published in 1899 in the journal "Libertas" by UST, July 14, 1899.

terms borrowed from Spanish language to talk about the Avant-Garde, that is Modernism in American-English tradition (Almario 1984; Reyes 2014). This question of terms underscores the need for revising studies on Philippine literatures. Not only the Spanish-American modernista trend in Philippine poetry is unjustly omitted in the extensive bibliography on Modernismo, with a few exceptions like Pedro Gimferrer's anthology (1969); Philippine literary 
criticism has not fully revisited Philippine literature written in Spanish yet. The First Filipino Writers Conference in 1940, which took place under the Commonwealth umbrella and with President Manuel Quezon's support for setting literary objectives, developed an interpretation of this poetry which highlighted how they were drawing upon Hispanic literature and culture, but undermining the struggling force and the nation projected within it (Reyes 2014). Unfortunately, that restrictive reading of Philippine literature written in Spanish has been transmitted without due revision. At the end of the twentieth century, some critical studies were done within the Department of European Languages at the University of the Philippines but remained unpublished or difficult to access (Coronel 1994; Peralta-Imson 1991; Bautista 1999). More recent and accessible articles by Donoso (2015), Ortuño (2014) and Álvarez (2013) have opened new paths.

\section{On the Way to Modernismo}

The culture and intellectual life of those countries under the dependence of the Spanish crown, Spanish America, and the Philippines did not directly undergo the spirit of Enlightenment nor Romanticism. The latter was a reaction against the former, but in Spain there was neither Enlightenment nor revolutions. The Spanish liberal thought at the beginning of the nineteenth century was crushed and banished. Without both intellectual currents, literature and thought in Spain were in a state of lethargy until the liberal revolution in 1868. Therefore, there was neither Enlightenment nor Romantic literature, as it is understood in Germany and England, in Spain, in Spanish America, or in the Philippines (Langer 1970; Jrade 1996). Therefore, "translation" was the term Octavio Paz used to describe it, borrowing the expression from the Argentinean Sarmiento who, visiting Spain in 1846, wrote "ustedes no tienen hoy autores ni escritores ni cosa que lo valga ... ustedes aquí y nosotros allá traducimos" ["You have no authors nowadays, nor writers, nor anything of any value ... you over here and we over there translate"] (Paz 118). However, as Paz puts it, Modernismo was their authentic metaphor: "the answer to positivism, the criticism of sensibility [...] to empiricism and positivistic scientism. In this sense its historical function was similar to 
that of the Romantic reaction in the early days of the nineteenth century" (88). Several Spanish American writers, in different places and sometimes without any communication with each other, began the change (Paz 130). The efforts of the writers and intellectuals were focused on attaining distinguishing features for their works and progress for their ideas and countries (Calinescu 69). In the words of one of the members, Leopoldo Lugones, Modernismo meant: La conquista de la independencia intelectual [the conquest of the intellectual independence] (Henríquez Ureña 52). Such unity found in Modernismo, which also crossed the ocean to the Philippines, was related to that "shared literary, philosophic, and social context" (Jrade 7). Therefore, for the Philippine writers it was their metaphor, too. It became the crucible intellectuals sought in order to establish a connection to a Pan-Hispanic entity (Quiroga 304), from which to get support for their Republic and fight for freedom against the neo-colonial power.

\section{Modernismo in Philippine Poetry in Spanish}

For the Philippine writers in Spanish, Modernismo meant a particular attitude and thought, a distinctive period in their intellectual history. Modernista literary and aesthetic concepts contributed to the formation of these authors' ideas for the building of the Philippine nation and their transmission through the poetic creation. The poems here discussed expand from 1898 to 1914 . Fermando Maria Guerrero's poem in his book, Crisálidas, is a compilation of poems from 1898 to the first edition in 1914, as Guerrero explained in his prologue. 1914 was also the year of the composition of Cecilio Apostol's poem dedicated to Spanish poet Salvador Rueda for his visit the following year. Apostol's poetry, written since 1898, was gathered in the book Pentélicas (1941).

The political situation and discussions on language had a turning point with the return in 1916 of Quezon from the United States to the country, the Jones Law of 1916 and its promise of Philippine independence, and the famous Bocobo-Osias debate on language in that same year (Tinio 187-190). The years between 1898 and 1914 were marked with turmoil and censorship. The single book of poetry that saw light in 1911 was published by Claro 
\&in. $\mathscr{N}$ efecto

BAJO LOS COCOTEROS

(ALMAS Y PANORAMAS)

Introito (Prólogo): Fernando M.a Guerrero.

Elosio:

Cecilio Apóstol.

Ito Missa est (Epilogo): Teodoro M. Kalaw.

Ilustraciones: . Fabián de la Rosa, Jorge Pineda y F. Amorsolo.

Rasgos musicales: Juan Hernández y Antonio Escamilla.

$$
* 2 *
$$

Libreria "MANILA FILATÉLICA"

Eolor, 453, Sta. Cruz.-Apartado de Ccrreos, 70 MANILA, 1911.

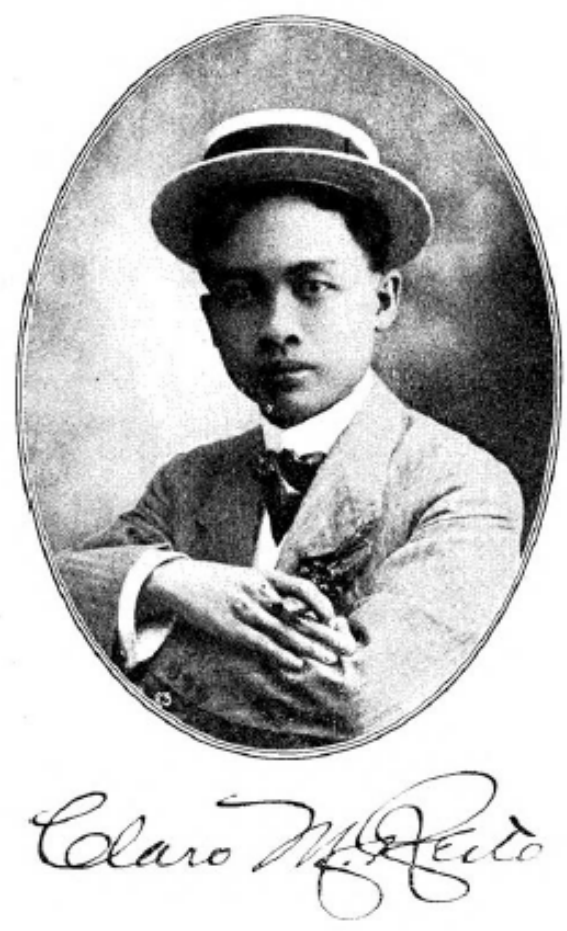

Fig. 2. Claro Mayo Recto book and portrait. 


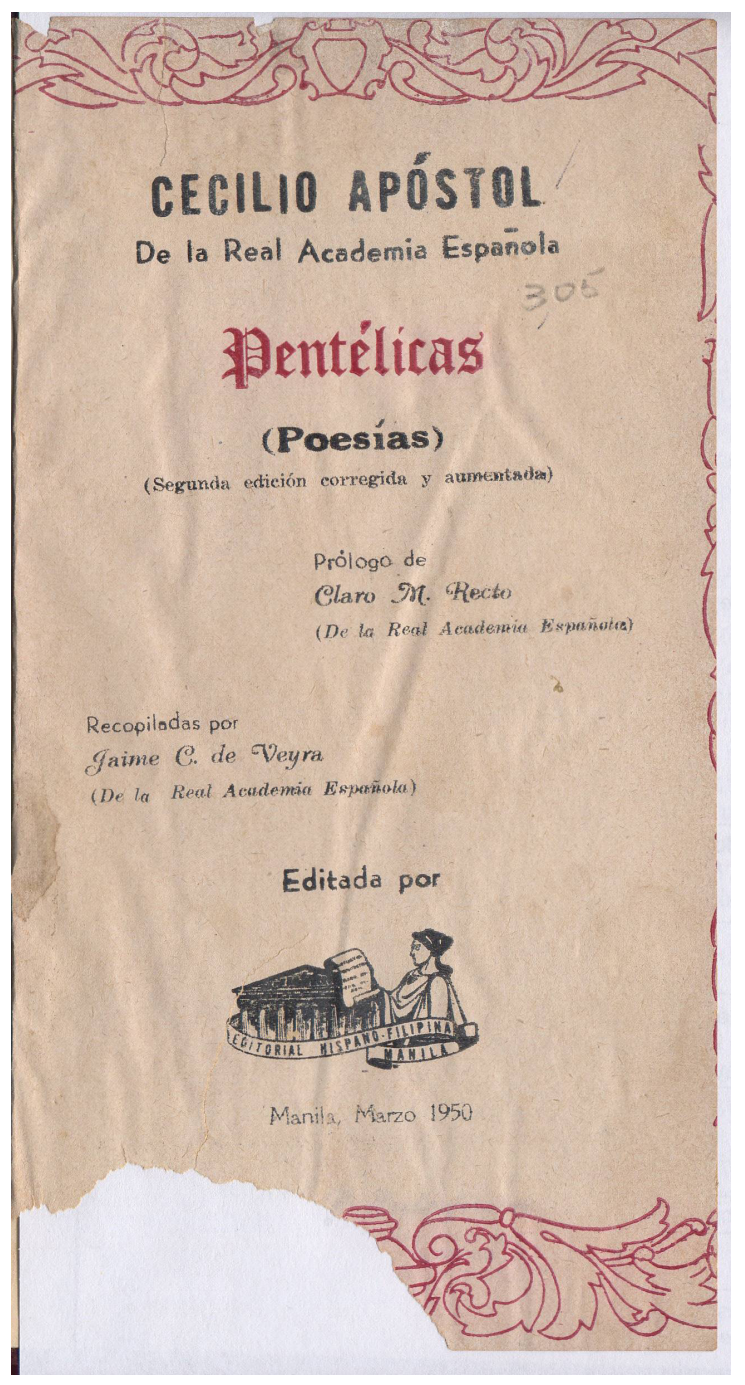

Fig. 3. Cecilio Apóstol book and photo with La Independencia staff, ca. 1898. 


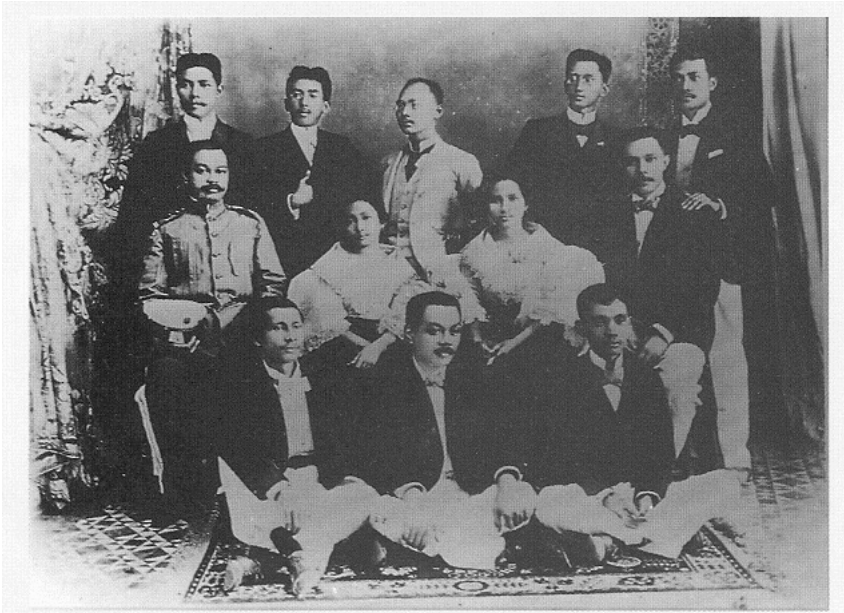

Revolution. The poems and essays of Andres Bonifacio (top) depicted in this Botong mural as the Katipunan supremo, stirred the revolutionary forces and fired their quest for independence. The newspaper La Independencia published essays and poems against the colonization of the islands by the United States. Its staff (above) included (first row) Fernando Ma. Guerrero, Joaquin Luna and Cecilio Apostol; (second row, left to right) General Antonio Luna (editor), Florentina Arellano, Rosa Sevilla and Salvador del Rosario; (third row, left to right) Mariano V. del Rosario, Clemente Jose Zulueta, Jose Abreu, Epifanio de los Santos and Rafael Palma.

Fig. 4. Fernando María Guerrero in the same photo with La Independencia staff, ca. 1898.

Mayo Recto, a young writer who soon after that book decided to put his efforts into essays and law issues. Not all the poems however have an exact known date. Many were written for special occasions and recited in public.

For the Philippine poets, Modernismo was the spirit of criticism that nurtured and encouraged their criticism of the positivistic and liberal neocolonialism from U.S. In like manner, "it was not a repetition" (Paz) but the embodiment of their luchas amargas [bitter fights] in the poems. The poetic body they produced helped the writers to search for the cognitive metaphors for the nation, that is, metaphors that framed the concept of the Philippines against the American campaign of disdain in the country. The contribution and relevance of this poetry should not be diminished but put in parallel to its milieu, the context of language politics. Poetry and poets were on the stage, 
at the center of the social life and debates, expressed in Spanish, in Tagalog, or in the other languages of the Philippines in the regions (Cullinane 2003; Tinio 2009). The political role played on these occasions and social events as part of the people's consciousness of the politics of language has been clearly identified in Tinio's dissertation on language politics (1-3). Protected by the seeming pettiness of banquets, birthdays, and engagement parties, these were gatherings of minds listening to ideas in poetic form. Thus, cognizant of those poetic implications, the American colonial authority was ready to press charges of sedition against a poem by Recto.

\section{Aesthetics and Language}

The poets looked for perfection in the form and renovation in the poetic expression and the language. New images and new words carried their preoccupations and ideas, which were also new and different from those of the preceding poetry, and far separated from the poetry in Spain at that time. They practiced different kinds of poetic meter. Although the alejandrino of fourteen syllables was the one preferred, lines of twelve and nine, not common before in Spanish poetry, were also abundant. Other innovations in meters, stanzas, and rhythms fell into the trend of modernista transformation. The essential was not to limit oneself to the canon since Modernismo was also the search for an individual style. In the renovation of the poetic expression, they modeled new images and metaphors using symbols of plastic beauty. The rose was a favorite poetic symbol used as a way of expressing the object of desire and perfection as well as a poetic image of what has been lost. One of the most beautiful examples is the offering of Recto, opening his book Bajo los cocoteros (1911), 
Permitid que os ofrende con ambas manos estas rosas primeras de mi jardín de ensueños. Son rosas pálidas, demasiado tristes, porque mi jardín está enfermo; pero huelen a corazón, a corazón atormentado que tiene estremecimientos de agua diáfana y sangra como un rosal.

(Ofertorio V)
Permit me to offer you with my both hands these initial roses from my garden of dreams. They are pale roses, very much in sorrow, for my garden is ill, although they exhale my heart's scent, a tormented heart who trembles like the clear water and bleeds like the rosebush ${ }^{2}$.

(Offering)

In an earlier poem of Guerrero, "Más que todo, mi cruz..." the rose was the life and all the dreams, which in the course of time became tears and thorns,

"Más que todo, mi cruz ..."

Hay un amor oculto en cada cosa, $y$ en cada cosa, una sutil tristeza, lo mismo en una rosa

Es justo. En mis jardines ya no hay rosas, sino espinas: jlas lleva mi cabeza!
"More than anything, My Cross..." There is a hidden love in everything, inside each thing, a subtle sadness, as there is inside a rose

It is proper. In my gardens there are
no roses any more
but thorns, thorns which my head wears!

The object of plastic beauty was a sacred symbol of poetic perfection, the aspiration to beauty the writer sought in the poem by shaping the word and the verse, the messenger of their ideals and hopes. Plastic images related to brightness, light, and color were also common like jewels, gems, or pearls. Guerrero's emeralds were the mystic and the unknown; the mystery Modernismo found in the beautiful, always strange, as in the relation between life and death, 


\section{"Esmeraldas"}

Estas son las maléficas, las piedras inquietantes

de fulgencias extrañas; piedras alucinantes

que son como pupilas de arañas fascinantes

al acecho de las pobres moscas errantes.
"Emeralds"

These are the cursing, disturbing stones

strangely fulgent; deluding stones like eyes of fascinating spiders stalking the poor errant flies.
Verde ... color amado de la fatalidad, matiz que está tejido de rayos de maldad.

Piedra verde, esmeralda ¿qué honda perversidad

emana de tu glauca y bruja claridad?

Esmeraldas: quizás por un supremo arcano

esté unido a vosotras todo destino humano...

No lo sé, pero os juro que vuestro brillo insano

es para mí de un muerto como el mirar lejano ...
Green ... the color fatality loves, shade woven with rays of evil. Stone of green, emerald, what deep perversion your glaucous and witchy light emits?

Emeralds: perhaps a supreme arcane binds you to every human fate... I don't know, but I swear that insane brightness of yours is for me of a death person the distant look...

Here the poet introduced the word "glauca" which is an example of the modernista innovations in the language. "Glauco", meaning clear green, was introduced in 1884. At the end of the 19th century, many other terms from Greek (like glaukós) were also incorporated into the language by the modernista writers (Corominas 1994).

Harmony and beauty were the principles that ruled the modernista aesthetic. The poem was a search for sensory impressions. The landscape, the melody, the aroma of a flower, a beautiful object, among others, were the sources of feelings. Plastic effects were produced through colors, from the brighter to the tenuous. One of the best examples of the creation of these sensorial images with all of them present are to be found in the same poem, 
"El alma de la raza" by Claro Recto (1909); wherein the soul of the race took shape through the senses: sight in the landscape and the colors; hearing in the melody; smell in the aroma; and touch and taste (please see the complete poem in the attachment).

\section{Lyricism and Escapism}

The escapism found in modernista writers is part of their reaction against society. Art is their support for the construction of different values more human and less materialistic, as explained by Ricardo Gullón,

The artist rejects the unsatisfactory reality (the social reality, not the natural), where he can neither feel integrated nor does want to join, and thus looks for ways of evasion. One of the paths, perhaps the most obvious, is opened by the nostalgia, and leads to the past; the other one, shaped by the dreams, leads towards the transfiguration of the distant (in time and space, or both at once), far from daily vulgarity ${ }^{3}$. (65)

For the Philippine writer, the cultural past and the Spanish heritage opened the path to a nostalgic way of evading the problems confronting the country at the-turn-of-the-century. The transfiguration of the distant took place in both directions: the past became remote and the presence of Spanish culture in Philippines emerged in their poems as a legend. The escapism towards the past and the Hispanic was not the act of supporting the Spanish colonial government; shaped by Modernismo, the far and away Spain was a myth in their words. Such "transfiguration of the distant" served a political purpose. This transmutation was a requisite to rise a bizarre Philippine identity confronting the US colonial intellectual weapons; had those artists regretted their Hispanic nutrients, perhaps American colonial power could have fought an easier and faster battle. The lyricism and escapism were set forth in this Cecilio Apostol's poem: 
"Lirismo"

Dejemos ya el trabajo del análisis. ¿A qué más, si al hundir el escalpelo, se apodera del alma la parálisis y premia su fatiga el desconsuelo?

Si te parece lo exterior pequeño $y$ estrecha la callada lejanía, podemos ir a la isla del Ensueño llevados por el cisne Fantasía.
"Lyricism"

Let's forget now the work of analysis. What for, if at the inserting of the scalpel paralysis seizes the soul and the effort is rewarded with sorrow?

If the external seems small to you and the silent distance narrow, let's go to the Island of Dreams brought by the Swan Fantasy.

The values and principles they yearned for were represented in archetypes of a legendary way of life, symbols they transformed in their poems, such as Dulcinea, the beautiful lady, the product of Don Quijote's imagination; Don Quijote himself; and the greatest and most universal writers of Spanish literature who appear in their poems. It is to their fictional Spain, not the one existing in real life that they escape. Spain is one of the symbols for their Avalon, but the Hispanic elements are not the exclusive recourse of writers' imagination. With further weight and significance, elements from Malayan, Tagalog, and other native cultures appeared in their poetry. Transformed through poetic experience, the Philippine natural landscape, the rituals, the ancient stories and legendary protagonists became the images and metaphors of the writers' thoughts: Mount Banahaw, the Philippine forest and sunset, flowers like sampaguita in the poems of Recto; the ilangilang flower, Manila, the Kundiman, in Guerrero's; and the Philippine landscape, the volcano, the sea, in Apostol's. Philippine historical and legendary figures together with leaders of the Revolution were the subjects of many modernista poems: Lakandula, Magat-Salamat, Tomas Pinpin, Jose Rizal, Marcelo H. del Pilar, Emilio Jacinto, Apolinario Mabini, Andres Bonifacio, Graciano Lopez Jaena, to name some. The hunger of the spirit was one of the preeminent marks of the modernista. Their admiration and love for the great past, whether Malayan, Tagalog, or Hispanic, was actually deep and sincere, 
yet they were not singing the deeds of individuals but the pettiness, selfishness, and ingratitude of their own generation. These attitudes, contradictory only outwards, were forced on intellectuals by the very fact that they were powerless to act or to affect the destiny of their country except in the realm of ideas, as expressed by Guerrero in "Las dos hoces",

"Las dos hoces"

Ya están en mis manos las dos sacras hoces

que el herrero anónimo para mí forjó: la de hierro duro, que es mi fortaleza, $y$ la de oro fino, que es mi ensoñación.

\section{“The Two Sickles”}

The two sacred sickles are already in my hands those the anonymous smith forged for me: one is hard iron, that is my vigor; the other fine gold, that is my fantasy.

\section{Philippine Modernista Thought and Language Politics: \\ A Valiant Poem of Granite}

The longing of the Philippine modernista poem was to become the stone where past and present were engraved, a cohesive site where the foundations of the coming nation they were creating and building were laid.

During the first years of American occupation, the essays published in the press, particularly in Muling Pagsilang, the counterpart newspaper of El Renacimiento, fought for Tagalog language and culture, showing a clever conceptualization of the Philippine nation with "confidence in and commitment" (Tinio 132). Such a defense struck Tinio, so she tried to remedy this lacunae by discussing the Tagalog and English essays about the Tagalog language in her dissertation. Reading and analyzing texts written in Spanish during those years can complete that lack of comprehension about the first years of the American occupation (117). This article aims at contributing to this purpose with Spanish poetry about Tagalog language and their conviction on their tasks as writers to help building the concept of the Philippine nation. Artists were searching for elements of cohesion through the creation of nation-building metaphors. Their cultural unity was rooted in Nature which supported the idea of a common sensory experience. This was the 
land lived by the community as a nation, as expressed through the lyrical and emotional way of knowing by Guerrero in "La isla hermana",

$\begin{array}{ll}\begin{array}{l}\text { "La isla hermana" } \\ \text { Un vinculo, más fuerte }\end{array} & \text { "Three Islands" } \\ \text { que el puño de los Césares y que la } & \text { A vinculum, stronger } \\ \text { misma muerte, } & \text { than Caesar's fist, than death herself, } \\ \text { makes the Three Islands only one } & \text { heart, } \\ \text { hace de las Tres Islas un solo corazón, } & \text { whe tendrá, en la ventura, una sonrisa } \\ \text { unica } & \text { whill, in happiness, have the same } \\ \text { y, en las adversas horas, sabrá rasgar } & \text { and, at time of adversity, will know } \\ \text { su túnica } & \text { how to fling one's dress clothes } \\ \text { con un definitivo y unánime tirón. } & \text { with one resolute, united effort. } \\ & \text { Aren't your beautiful nights } \\ \text { ¿No son tus noches bellas } & \text { the same as ours? Doesn't the light of } \\ \text { las mismas que las nuestras? ¿no es luz } & \text { your stars } \\ \text { de tus estrellas } & \text { shine together over Bisayas and } \\ \text { la que reciben juntas Bisayas y Luzón? } & \text { Luzon? } \\ \text { ¿No es el aroma indígena del ilang-ilang } & \text { Doesn't the aroma of the royal ilang-il- } \\ \text { regio } & \text { ang } \\ \text { el que a leer nos mueve un solo flori- } & \text { move us to read a single poem, to feel } \\ \text { legio } & \text { deeply inside our soul, a single senti- } \\ \text { y a sentir, alma adentro, una sola } & \text { ment. } \\ \text { emoción? } & \end{array}$

Their tone was confident and optimistic, as seen in the above "Three islands" by Guerrero, in "Soul of the Race" and "The Crucible of the Race" by Recto, and "To the Anonymous Martyrs of the Country" by Apostol. Their strength came from a confidence like that of the poet Santos Chocano (Peru 1875-1934) who was admired and read by many of the Philippine writers. Besides the natural elements, other bricks for the nation were their old traditions and legends, as expressed by Guerrero, 
"Adulterada ... jNo! ( A la Patria)"

¡No morirás!... Tus bravos aborígenes, curtidos en la lucha y la borrasca, velan por tus leyendas tan antiguas como el sol que corona tus montañas...
"Adulterated ... No! (To The Country)" You will not die! ... Your valiant natives, forged in the struggle and the storm, guard your legends as old as the sun crowning in your mountains ...

Notwithstanding the status awarded to the Spanish language as a major instrument for opposition to the imposition of English, the native language was equally part of the patria. The language of the kundiman and Balagtas, Tagalog, was the language Recto was praising and recognizing as fundamental for the Philippines,

\section{"La lengua del terruño" \\ Es la lengua sagrada de rajáhs y sultanes, \\ de régulos que alzaban su trono en los volcanes \\ y enviaban sus guerreras piraguas a la mar. \\ A través de los siglos fue incólume su gloria; \\ es la página de oro en la malaya \\ historia \\ que simboliza el alma del nativo solar.}

Ella encarna la patria, sus glorias ella encierra,

por eso, ella es eterna, como eterna es mi tierra,

$y$ eternos son los héroes de nuestra libertad...
“The Native Language”

'Tis the sacred language of the rajahs and sultans,

of chieftains who raised their thrones on volcanoes

and sent their warring piroques to sea.

Through the centuries their glory was unharmed;

In Malayan history 'tis the page of gold

that symbolizes the soul of the native land.

It incarnates the country, treasures her glories,

that's why it is eternal, as eternal is my land,

and eternal are the heroes of our freedom ...

(Alfredo S. Veloso's translation)

Poetry in Spanish also contributed to the success of Tagalog in the Philippines. In order to understand its relevance, it must be put into the 
context of language politics. The significance of the concept of lahi in Tagalog, discussed by Tinio (150-154), was the connection between language and nationhood; apparently, it was intrinsically related to its development in Tagalog language. However, it was also developed in Spanish and in poetry, as it is shown here. The concept can be identified in this poem of Recto, although the word itself did not appear. The poem began connecting the Tagalog language to history, to Nature's sounds, then to emotions, to love confidences, to the Arts, and to the spreading of the Revolution. In the last stanza, language embodies the nation and the repository of the glory, so that language, as well as the land, are eternal; therefore, those who fought for the freedom of that land and that language are eternal too. Note that in Veloso's translation the Spanish word patria is translated as "country"; nevertheless patria is closer to lahi, in the sense of motherland or fatherland, that is, the place of "my heritage" and "my people", which is directly related to the poem's title: "La lengua del terruño", meaning "the language of my origins".

Another term was also quite relevant: malaya. As writers did when discussing in Tagalog language, in Philippine poetry in Spanish, "Malay" was used in many poems, as in the above poem of Recto. Their concern about unifying the islands and the people, already shown in "La isla hermana," brought the use of "Malay" in the same way explained by Tinio (158). The poets rescued and reinvented their ancestry. "Malay" was the word for their history and civilization, that is, a word equal to the terms for other civilizations such as "European" or “American." By using the spirit and the tools Modernismo equipped them with, Filipino poets created this "Malay" reinvention.

Defending the country's heritage against the neocolonialism from the United States placed the Spanish language in a special status. Spanish had a privileged position against English because of the American discourse about the lack in civilization of Philippine languages; that was the position in which American colonial power placed Spanish (Tinio 100). The US government had its own fight against Spanish in the Philippines as they would deem it worth enemy, and therefore belittled the vernacular languages. The attack on the Spanish language was so strong that Filipinos felt insulted, because it was their language, too. In the outpost, Spanish would lead the fight against 
the new colonial power, the famous libel case of El Renacimiento being just a symbol of it. In return, the ruin of Spanish helped lead to the success of Tagalog. In the following example from Apóstol, Spanish language was an inspiration for independence against US influence,

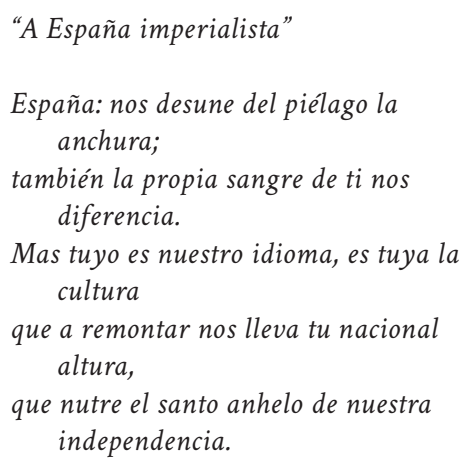

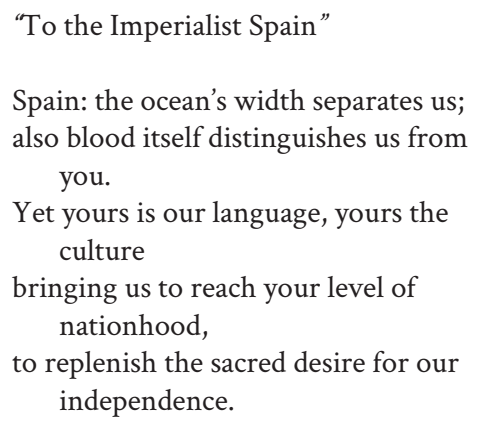
independence.

The task of the intellectual was to set a high example, both in the moral and the cultural sphere, and to call not only for the creation of a culture but also for the preservation of the culture of the past. Recto called for action beyond the reality of the present, the actions of the intellectuals had to aim at the future,

\section{"Epopeya de la raza"}

Está ya muerto el presente...

Libertarlo es imposible, porque ha sido condenado.

Pues, entonces, libertemos el futuro, custodiando la simiente

que han echado

en el surco de las almas

nuestros heroes que murieron, conquistando eternas palmas.
"The Crucible of the Race"

The present is already dead ...

'Tis impossible to liberate it for it has been condemned.

So let's then liberate the future, guarding the seed

that was sown

in the furroughs of the souls

by our heroes who died conquering eternal palms.

(Alfredo S. Veloso's translation) 
The task of the intellectual was to bring modernity to the country. Modernity is not used here as a historical period but a quality, a condition, in the spirit of betterment towards the future, although connected to the Enlightenment ideas regarding modern age. In the Philippine context, the debate may be put in the same terms discussed by Sharman (13-15) for Latin America, framed by the formation of the nation-states as an emancipating, democratizing, and renovation project from the elites and the cosmopolitan groups; thus, it enters in conflict with the multiplicity of realities and societies in the country. In Philippine literature in Spanish, an epitome of this tension is the long poem by Fernando Canon, "A la laguna de Bay," for whom Modernismo plays a relevant role, too (Alvarez 2013). Among the writers discussed here, it was Apóstol who sang more explicitly to modernity in "Excelsior," (1901) a poem dedicated to the memory of George Washington, who represented all those ideals which contrasted with what the United States had brought to the Philippines. Apostol started with a salutation from a free man,

"Excelsior"

¡Salud al genio! El canto de mi lira es débil, sí, pero dejad que vibre: nace del corazón de un hombre libre, que la virtud por la virtud admira.
"Excelsior"

Hail to the genius! The song of my lyre is feeble, yes, though let it sound: it was born in the heart of a free man, who, for its virtue, virtue admires.

by Apóstol (1901)

Washington is a great figure in the history of America. Law and Human Rights were his ground for the construction of their independence. According to Apostol, no poet had yet been capable of praising his deeds and only a poem as powerful as a mountain that was "a valiant poem of granite to the infinite" could have made justice to the Ideas of Washington: 


\section{"Excelsior"}

¡Salud al héroe de alma gigantea, que halló un punto de apoyo en el

Derecho

para mover un vasto continente

con la inmortal palanca de la Idea!

El verbo humano, a las bajezas hecho

de la vida banal, es impotente;

no puede ni ha podido todavía

alzar al infinito

un bizarro poema de granito

en loor del más grande entre los gran-

des.

\section{"Excelsior"}

Hail! to the hero of the giant soul, who found a pivot in justice

to conduct a vast continent

with the immortal fulcrum of the Idea!

The human word, moulded in the pettiness of ordinary life, is helpless;

cannot, still has not been able

to raise to the infinite

a valiant poem of granite

in praise of the greatest amongst the great.

Washington's figure and ideas did not belong to one country but were "cosmopolitan." The poet claimed that "sacred Liberty, the goddess of the cult of the modern spirit" should not be denied to the "new possessions," precisely by those who ought to Washington what they were:

No te nieguen jamás los que han hallado, por tus lecciones que conserva escritas el arca de las viejas tradiciones venturas mil en su triunfal camino, hoy que trazan la ruta del destino que han de regir las "nuevas posesiones".

ique el polen inmortal de tus doctrinas venga muy pronto a fecundar el seno de mi querida Patria Filipinas!
You shall never be denied by those who found

through your lessons preserved in the records

in the coffer of the old traditions, thousand adventures in the way to victory, those who now trace the route of destiny that should govern the "new possesions"

that the immortal pollen of your doctrine arrive soon to fertilize the bosom of my dear country Philippines! 
Cecilio Apóstol was the first to introduce the theme of the "Idea" in 1898, in the poem "A los mártires anónimos de la patria" ["To the Anonymous Martyrs of the Country"] (see Attachment), and in the better known and powerful poem written in honor to Jose Rizal,

\author{
"Al héroe nacional" \\ ¡No llores de la tumba en el misterio \\ del español el triunfo momentáneo, \\ que si una bala destrozó tu cráneo \\ tu Idea, en cambio, destruyó un imperio!
}

\begin{abstract}
"To the National Hero"
Weep not over the silence of your tomb over the fleeting Spanish triumph for if a bullet destroyed your cranium your idea, in turn, destroyed an empire!
\end{abstract}

The "Idea" was a poetic inspiration for many later poems of the three writers. As a metonymy, it served different purposes: it was the source of energy and change; it provided strength and encouraged people to resist; it was the vehicle of independence, freedom, future; it was the "Idea," too, of the Philippines, or how they envisioned the nation in the future, how they represented it in the poems, and no less relevant, how they conceptualized a frame powerful enough to resist the American occupation. The Idea was a stone and the stone took shape in the poem. The "Idea" served to join the foundations of the different currents, as expressed by Guerrero,

\author{
"Una fe y un corazón" \\ Oid, hombres de mi raza: no progaguéis \\ semillas \\ de división; poneos como ayer de \\ rodillas \\ ante una misma idea y ante un único \\ altar.
}

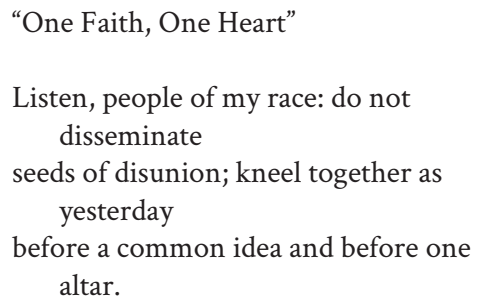
altar.

The "Idea" embodied the nation-building concepts and the projects for independence, which could not be explicitly expressed. Poems of modernista 
aesthetics, with dreamlike images and charged with lyricism, described the existence of the "Idea." The association of the "Idea" of the Philippines with the figure of a woman is worth considering for further research on how women incarnated in literature the nation or the idea of the Philippines, like in the following poem by Guerrero,

$\begin{array}{ll}\text { "Psyche" } & \text { "Psyche" } \\ \text { Va el alma ... } & \text { The soul sails ... } \\ \text { Como buque misterioso } & \text { like a mysterious vessel } \\ \text { surca el mar del Ensueño. } & \text { over the ocean of dreams. } \\ \text { La ola eterna de la vida la arrulla, } & \text { Life's eternal wave lulls it, } \\ \text { y sobre el férvido océano ideal por } & \text { bobbing over the effervescent, perfect } \\ \text { donde viaja, } & \text { sea, } \\ \text { hay como un rompimiento de crepús- } & \text { a burst of twilights, of new suns } \\ \text { culos, } & \text { between whose rays } \\ \text { de soles nuevos entre cuyos rayos } & \text { the figure of a woman wanders: the } \\ \text { vaga una forma de mujer: la Idea. } & \text { Idea. }\end{array}$

Modernista Philippine poetry in Spanish was a site of resistance through a process of creating metaphors whose purpose was to fight for and to conceptualize the nation. Claro M. Recto was close to facing charges for sedition in his youth because of a poem, as earlier mentioned. The potential of his text was unrecognized by the city fiscal who did not pursue the charges; thus, poetic aesthetics had saved Recto from imprisonment. Poems were stones thrown to counteract the discourse of the foreign, a form of defense against the American colonial government that underestimated the value, for example, of Philippine history, culture, languages, and social ways.

This article has attempted to describe the most influential notions expressed in their poems: the Philippines formed a nation and a cultural unity with roots in the different civilizations prior to the arrival of Spanish people and in Hispanic civilization, too. The defense of the country's heritage against neocolonialism under the United States included the defense of Tagalog language due to the position of the Spanish language had against American discourse about the lack civilization of Philippine languages. 
The poems pointed to the tasks of the intellectuals in their milieu which included: setting a high example, both in the moral and the cultural sphere; creating not only a culture but also preserving the culture of the past; and bringing modernity, in terms of modernness, to the country. The conviction that guiding ideas shaped societies and the "Idea" were the sources of energy and change towards a better future. The colors of Modernismo acquired distinctive tones in each of the writers looking for the appropriate and perfect formula for the Philippines, a country to which they saw themselves as members and for which they would struggle. This essay is meant to be a tribute to these three poets,

Que vuestras ... rimas perfectas den, como premio a vuestras luchas amargas, el provocar en las almas selectas repercusiones profundas y largas.
That your ... perfect rhymes, as the reward for your bitter fights, serve to awaken in fine souls deep and lasting repercussions.

from Apóstol, Elogio del poeta

(A Claro M. Recto)

"In Praise of the Poet"

[To Claro M. Recto] 


\section{Appendix}

\section{Selected Poems}

"El alma de la raza" ["The Soul of the Race"] by Claro Recto (1909) [Translated by Alfredo S. Veloso].

The sight and the landscape:

Mi raza tiene un alma que es alma de titanes.

Es río que serpea bajo cañaverales, copiando en el encanto de sus claros cristales

la azul inmensidad.

Pero es también océano que derrumba montañas,

cuando en el seno obscuro de sus vastas entrañas

hierve en iras volcánicas su sed de libertad.

The sight and the colors:

Es tricolor su enseña ... Tiene el azul del Arte,

la blancura del lirio y la rojez de Marte,

Es silfide ligera de fantásticos vuelos, virgen como sus selvas, azul como sus cielos,
My race has a soul that is of Titans.

'Tis a river that meanders beneath bamboo groves, copying in the enchantment of its clear crystals the blue immensity.

But it's also an ocean that crushes mountains,

when in the dark bosom of its vast entrails

boils in volcanic fury its thirst for freedom.

Its emblem is tri-colored ... It has the blue of the Arts, the whiteness of the lily and the red of Mars,

'Tis a light sylph of fantastic flights, virginal like its forests, blue like its skies, 
Hearing and the melody:

Es suave como el ritmo de las flautas bucólicas

que ensaya dulcemente en notas melancólicas,

entre las verdes cañas, la brisa vesperal.
It's gentle like the bucolic flutes the twilight breeze sweetly plays amongst the green bamboos in melancholic notes.

The aroma:

Es ánfora de encantos, palacio de grandezas,

castillo de heroismos, santuario de bellezas,

refugio de los besos del oloroso Abril.

The touch and the taste:

Sabe pulsar la cítara con melodioso acento,

lúgubre como un cisne, triste como un lamento,

si se siente morir.

Sabe pulsar la cítara en arpegios bullentes,

como del champagne rubio los topacios hirvientes,

cuando su pecho embriaga la dicha del vivir.
'Tis an amphora of enchantments, palace of grandeurs, castle of heroisms, sanctuary of beauties, refuge of the kisses of fragrant April.
It knows how to pluck the cythara with melodious accent,

mournful like a swan, and doleful like a lament,

if it feels like dying.

It knows how to pluck the cythara in lively arpeggios,

like of the champagne the bubbling topazes,

when its breast is drunk with the joy of living. 
Literary attack of neo-colonialism:

"Al 'Yankee”"

Cuando al santo Derecho se trucida en el festín de la ambición humana; cuando como los yankees, a cañonazos brindan una patria;

Against American utilitarianism:

\section{"A Magat-Salamat"}

En este tiempo de los maleficios, del Rey Dólar que inspira a la Autocracia $y$ somete al dolor de los suplicios el alma de la antigua Democracia;
"To the 'Yankee"

When sacred justice is sacrificed in the banquet of human ambition; as when the yankees, toast a nation to the sound of cannon

by Apóstol (1899)

In these accursed times, when the omnipotent Dollar tempts the Autocracy and subjects to the pain of tortures the soul of the elder Democracy;

Guerrero (1910) 
Describing the new colonialism:

"Epopeya de la raza"

Ha pasado la hecatombe...Hoy, paz, mutua tolerancia

fraternidad simulada ... Ya el Águila es absoluta.

Y la Patria Filipina, la República impoluta,

marchitada en su infancia

por la extraña fuerza bruta,

a la sombra soberana

de sus alas se guarece,

de pie sobre sus escombros, ante la cruz

del Patriota

que el vencimiento ennoblece,

risueña ante la catástrofe, altanera en la derrota,

en espera del mañana.

In praise of Washington:

\section{"Excelsior"}

Los actos de tu vida de Espartaco los tienen siempre en la memoria fijos cuantos en esta vida tormentosa fueron ungidos por el beso eterno de la sagrada Libertad, la diosa del culto del espíritu moderno.
"The Crucible of the Race"

The hecatomb passed ... Now, peace, mutual tolerance

feigned fraternity ... The Eagle is already absolute.

And the Philippine nation, the unpolluted republic, withered in its infancy by brutal foreign force, beneath the sovereign shade of its wings is sheltered, standing over the rubbish, before the

Patriot's cross

that defeat ennobles, smiling before the catastrophe, haughty in defeat, awaiting the morrow.

Recto, (1910)

[Translated by Alfredo S. Veloso]

"Excelsior”

The deeds of your Spartan life are forever fixed in the memory of those who in this tormented life were anointed by the eternal kiss of sacred Liberty, the goddess of the cult of the modern spirit.

by Apóstol (1901) 
Those are the Americans who live in freedom, but Liberty will be the yearned Dulcinea for the oppressed:

\section{"Excelsior"}

¡Oh Libertad, oh santa Dulcinea de los hombres y pueblos oprimidos!

Hoy, como ayer, mientras el mundo sea, vivirás con tu corte de escogidos,

\section{"Excelsior"}

Oh Liberty, oh Saint Dulcinea of the oppressed people and countries! Today, as yesterday, as the world is, you shall live in the court among the chosen,

by Apóstol (1901)

The "Idea" in Cecilio Apóstol (1898):

"A los mártires anónimos de la patria"

Sacerdotes del templo de la Idea, cantores de las glorias de mi Patria, vosotros que sabéis con vuestras trovas penetrar en el fondo de las almas;
"To the Anonymous Martyrs of the Country"

Priests of the temple of the Idea, singers of the glories of my country, you, who with your poems know how to penetrate depths of souls;

by Apóstol (1898)

The "Idea" as a powerful tool for resistance:

"Allons, enfants..."

¡La idea de la fuerza es poderosa, mas no vence a la fuerza de la idea!
"Come, children..."

The idea of force is powerful, yet does not defeat the force of the Idea!

by Apostol 
"Epopeya de la raza"

Paladines de Idea, portadores del Progreso

Espartacos y Kokziuskos de la Causa filipina,

invencibles bajo el peso

de tres siglos de Conquista,

Es la fecha que registra en los fastos de la historia

la caida de un Apóstol, con temblor de cataclismo,

por el triunfo de una Idea, por un ansia de victoria,

el desplome de un Imperio de Conquista $y$ Despotismo,

Con la esteva del obrero y el verbo parlamentario

florecerá en el Calvario

el Gran Árbol de la Idea.
"The Crucible of the Race"

Knights of the Idea, bearers of Progress,

Spartacus and Kosciusko of the Philippine Cause,

invincible under the weight

of three centuries of Conquest,

'Tis the date that records in the pageantry of history

the fall of an Apostol, with the tremors of a cataclism,

for the triumph of an Idea, a longing for victory,

the toppling of an Empire of Conquest and Despotism,

With the laborer's plow-handle and the parliamentarian word the great Tree of the Idea shall bloom in the Calvary.

by Recto (1910)

[Translated by Alfredo S. Veloso] 


\section{Notes}

1. “A valiant poem of granite to the infinite" by Cecilio Apóstol (1901).

2. All translations are ours unless otherwise indicated.

3. Our translation of the original: "El artista rechaza la indeseable realidad (la realidad social: no la natural), en la que ni puede ni quiere integrarse, y busca caminos para la evasión. Uno de ellos, acaso el más obvio, lo abre la nostalgia, y conduce al pasado; otro, trazado por el ensueño, lleva a la transfiguración de lo distante (en tiempo o en espacio, o en ambos); lejos de la vulgaridad cotidiana" (Gullón 65). 


\section{Works Cited}

Agoncillo, Teodoro. History of the Filipino People. 8th ed., Garotech Publishing, 1990. Almario, Virgilio. Balagtasismo Versus Modernismo. Ateneo de Manila UP, 1984.

Alvarez Tardio, Beatriz. “Hay un caimán!”: Una aproximación al estudio del poema

A la laguna de Bay de Fernando Canon." Kritika Kultura, [S.1.], no. 20, 2013, pp. 129-171, doi:10.13185/KK2013.02007.

Apostol, Cecilio. Pentélicas (Poesías). Manila Gráfica, 1941.

Bautista, Erwin Thaddeus. "Cosmopolitanism in the Poetry of Manuel Bernabe." Philippine Humanities Review, vol. 3, no. 1, 1999.

Calinescu, Matei. Five Faces of Modernity: Modernism, Avant-garde, Kitsch, Postmodernism. $2^{\text {nd }}$ ed., Duke UP, 1987.

Corominas, Joan. Diccionario etimológico de la lengua castellana. Editorial Gredos, 1994.

Coronel, Reynaldo D. Jr. "Prolegomena al Estudio Semiótico de la Metáfora: La Poesía Lírica de Jesús Balmori.” 1994. University of the Philippines, PhD dissertation. Cullinane, Michael. Ilustrado Politics: Filipino Elite Responses to American Rule, 18981908. Ateneo de Manila UP, 2003.

Donoso, Isaac. "Relaciones Culturales Filipino-Persas (I) Las Rubaiyat De Manuel Bernabé." Revista Filipina, Segunda Etapa. Revista semestral de lengua y literatura hispanofilipina, vol.2, no. 2, 2015, pp. 58-68. www.revista.carayanpress.com/ page16/styled-41/page59/index.html.

Franco, Jean. An introduction to Spanish-American Literature. Cambridge UP, 1994.

Guerrero, Fernando Maria. Crisálidas (Poesías). $1^{\text {st }}$ ed., Philippine Education Foundation, 1914; $2^{\text {nd }}$ ed., 1952.

Jrade, Cathy L. "Modernist poetry." The Cambridge History of Latin American

Literature, edited by Roberto Gonzalez Echevarria and Enrique Pupo-Walker, Cambridge UP, 1996, pp. 7-68.

Langer, William L. "Western Civilization: The Struggle for Empire to Europe in the Modern World." Hangups From Way Back (Historical Myths and Canons, Volume I), edited by Frederick Gentles and Melvin Steinfield, Canfield Press, 1970.

Lumbera, Bienvenido L. and Cynthia Nograles Lumbera. Philippine Literature: A

History and Anthology. Revised ed. Anvil Publishing Inc., 1997.

Gimferrer, Pedro. Antología de la poesía modernista. Barral Editores, 1969.

Gullón, Ricardo. Direcciones del modernismo. $2^{\text {nd }}$ ed., Editorial Gredos, 1971.

Henríquez Ureña, Max. Breve historia del modernismo. Fondo de Cultura Económica, 1978. 
Ortuño Casanova, Rocío. "La representación de España en la poesía filipina en castellano de la época de ocupación americana: idealización, exotización y diferenciación.” Transmodernity, vol. 4, no. 1, 2014, pp. 154-167. escholarship. org/uc/item/7pd0p015>.

Paz, Octavio. Los hijos del limo: del romanticismo a la vanguardia. $2^{\text {nd }}$ ed., Seix Barral, 1989; as Children of the Mire. Modern Poetry from Romanticism to the Avant-Garde, translated by Rachel Phillips, Harvard UP, 1991.

Peralta-Imson, Maria Elinora. "The Poetry of Manuel Bernabe: Prolegomena to Reading a Cultural Text." 1991. University of the Philippines, PhD dissertation.

Quiroga, José. “Spanish American poetry from 1922 to 1975.” The Cambridge History of Latin American Literature, edited by Roberto Gonzalez Echevarria and Enrique Pupo-Walker, Cambridge UP, 1996, pp. 303-364.

Recto, Claro Mayo. Bajo los cocoteros (Almas y panoramas). Manila Filatélica, 1911.

Reyes, Maria Luisa Torres. "Modernity/Modernism in Philippine Literature." Journal of Language and Literature, vol. 14, no. 1, 2014, pp. 20-33. e-journal.usd.ac.id/index.php/JOLL/article/view/390/337.

Sharman, Adam. Tradition and Modernity in Spanish-American Literature: From Dario to Carpentier. Palgrave Macmillan, 2006.

Tinio, Maria Teresa Trinidad. The Triumph of Tagalog and the Dominance of the Discourse on English: Language Politics in the Philippines during the American Colonial Period. 2009. National University of Singapore, PhD dissertation. 